\title{
Structure and Geomorphology of Shaikhan Anticline- Northern Iraq
}

\author{
Nabeel K. Al-Azzawi ${ }^{1}$ and Alaa N. Hamdoon ${ }^{2}$
}

\begin{abstract}
Tectonic analysis of the Shaikhan Anticline in northern Iraq has been carried out using the available remote sensing data. The interpretation of aerial photographs and satellite images was correlated in the field with the ground truth, namely structural and geomorphologic features. It has been shown that the Shaikhan Anticline is located over and parallel to a listric fault in the basement rocks. Reactivation of this fault was basically responsible for the geometrical configuration of the Shaikhan Anticline. The listric fault is manifested in the form of a lineament on the satellite imagery and aerial photographs. This fault has cut through the sedimentary cover by normal sense of movement. It shows a small displacement on the beddings of the Pila Spi Formation along the northeastern limb of the anticline.
\end{abstract}

\section{تركيبية و جيومورفولوجية طية الثيخان المدبة / شمال العراق}

\author{
علاء نبيل حمدون \\ نبيل قادر العزاوي \\ مركز التحسس النائي/ جامعة الموصل \\ علوم الارض/جامعة الموصل
}

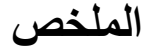

أجري التحليل التكتوني لطية الثيخان المدبة باستخدام معطيات التحسس التائي. ظهر من

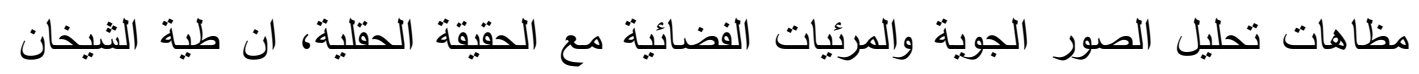
المحدبة واقعة فوق وموازية لفالق لستيري قاعدي وان اعادة الحركة على هذا الفالق كانت لها

السيطرة على هندسية هذه الطية. ظهر هذا الفالق على شكل تراكيب خطية في الصور

الجوية والمرئيات الفضائية. لقد كانت لاعادة الحركة على هذا الفالق في عصر الايوسين الطين

الاعلى السبب في تغاير سمك تكوين البلاسيي في جناحي الطبة، وان أستمرارية هذه الازاحة

قد قطعت الغطاء الرسوبي وظهرت على السطح لكن بازاحة قليلة.
\end{abstract}

1- Geology Dept. /College of Science / University of Mosul.

2- Remote sensing Centre / University of Mosul. 


\section{INTRODUCTION}

Shaikhan Anticline is one of the major structures in the Foreland Fold Belt (commonly called the Folded Zone) of Iraq. It is located in the northern part of Iraq, about (50) km north of Mosul city, and slightly north of Ain Sifni town (Fig. 1). Field observation has revealed that Shaikhan Anticline is asymmetrical and verging towards the northeast. Its northwestern plunge merges the southeastern plunge of Brifca Anticline near Mamiz Dina village and it is extended about (27) $\mathrm{km}$ southeasterly and plunge near Kavrasor village. Ahmad (1980) studied part of this structure and described the general characteristics of this anticline. Al-Azzawi (2003) studied this anticline by Fourier series analysis through a scope of regional study of the Foreland Folds Belt of Iraq

Stratigraphically, the structure embraces the following exposed formations. The Bekhme Fn. (Upper Cretacous) has basal conglomerates comprising globigerinal and foraminiferal limestones, reefal-detrital limestones and bituminous secondary dolomites. The Kolosh Fn. (Paleocene - Lower Eocene) is composed of shale, fine sandstone and fragments of various grains of green-rock, chert and radiolarite. The Gercus Fn. (Middle Eocene) is composed of red and purple shales, mudstones, sandy and gritty marls. The

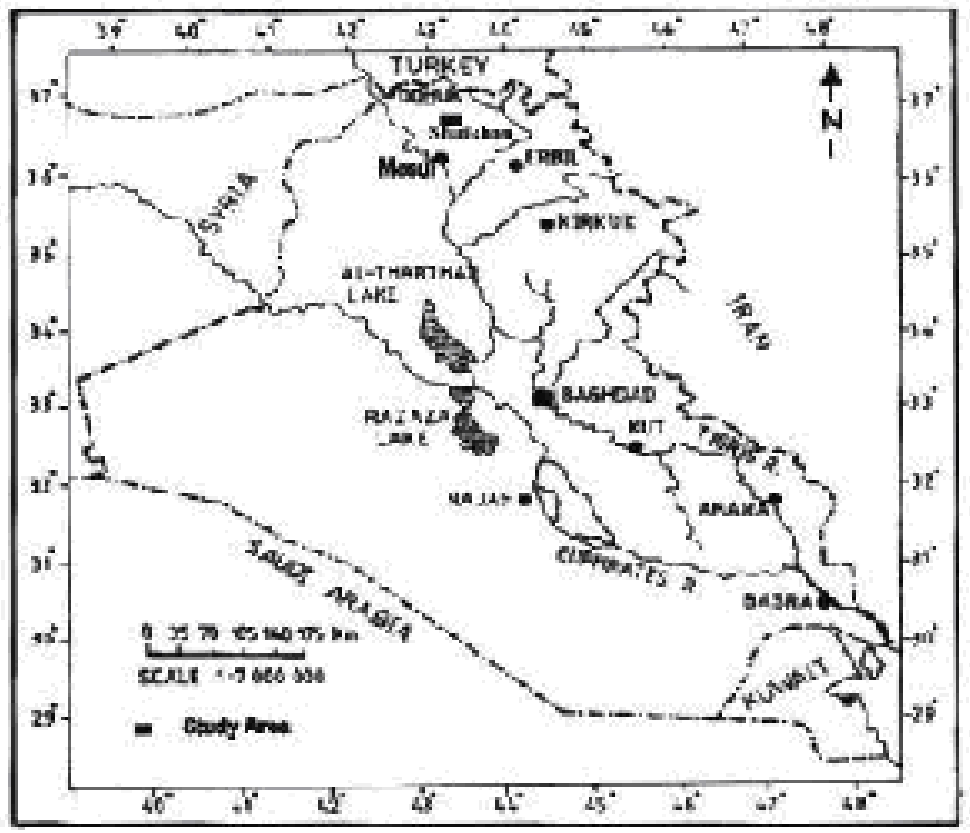

Fig.1. Location map of the study area

Pila Spi Fn. (Middle to Upper Eocene) consists of bedded limestones, hard, chalky appearance, porous or vitreous, bituminous or white and poorly fossiliferous. The Fat'ha Fn. (Middle Miocene) consists of gypsum and salt intercalated with limestones and marls. Finally the Injana Fn. (Upper Miocene) is composed of subcontinental and continental purple, red, brown and grey marls, silts, siltstones, sandstones and grits. The brief description of the lithology of each formation was taken from Van Bellen et al. (1959). 


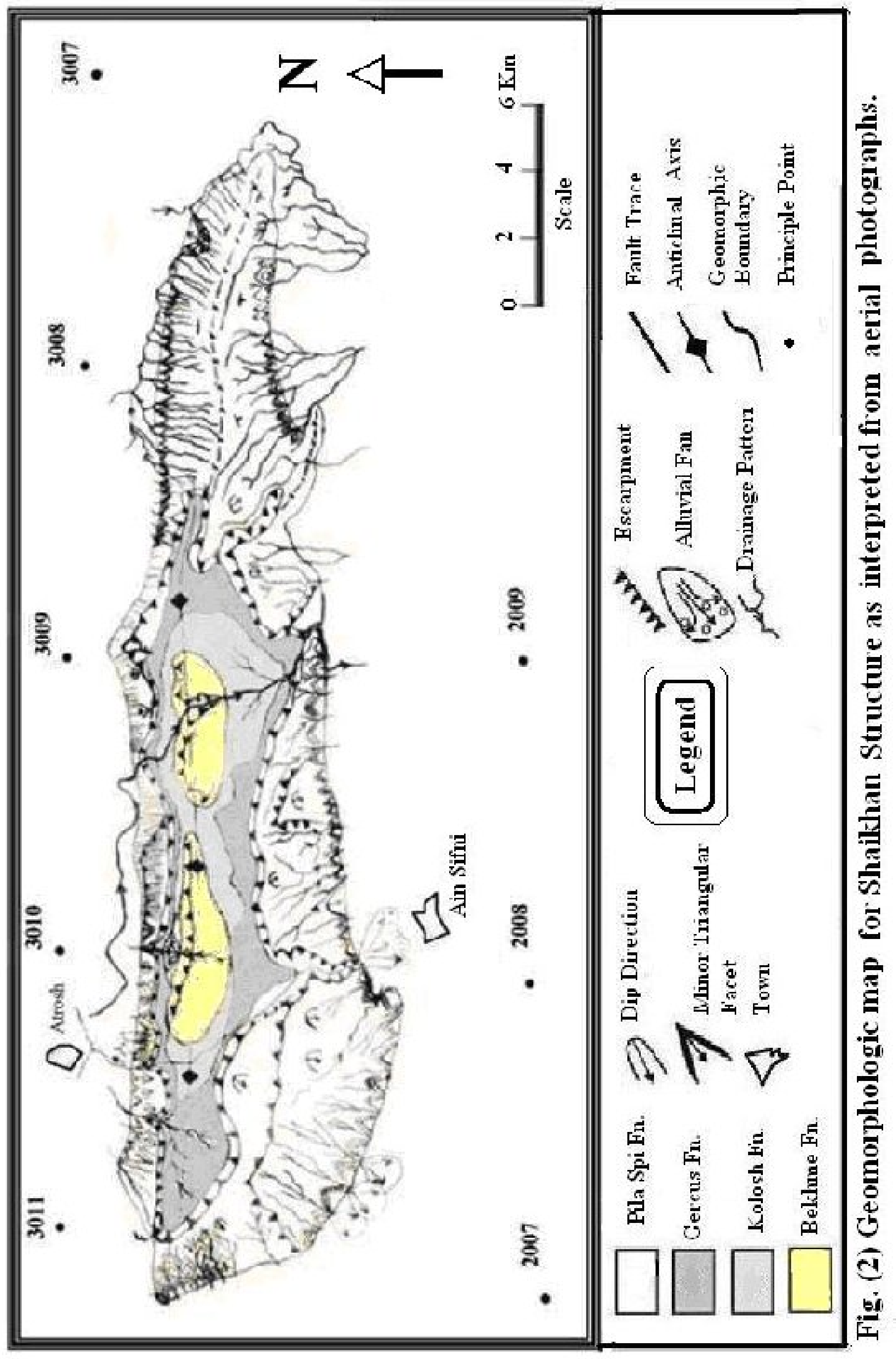


because it influenced by a listric fault (Numan and Al-Azzawi; 1993, AlAzzawi; 2003). The purpose of this work is to study the geomorphology and structural features of this area with particular emphasis on the interplaying of the basement listric fault, in an attempt to explain how this fault influenced the geometry of Shaikhan Anticline and to determine the type and amount of the fault displacement.

\section{GEOMORPHOLOGY OF SHAIKHAN ANTICLINE}

A geomorphologic map was made from the interpretation of aerial photographs (Fig. 2). An important and new feature found during this interpretation which was called a butterfly due to its shape. The butterflies have straight northern sides and coincide with the fault trace that was identified on the satellite image. The other sides are convex towards south. These features became important indications for fault traces (Fig. 2). The presence of the fault trace was verified by using other geomorphologic features like lineament and triangular facets as well as the butterfly shapes. This interpretation converged with the interpretation of the satellite imagery and the ground truth.

There are other two parallel lineaments which are indications for other two faults. These lineaments are manifested by the displacements in the Kolosh and Gercus formations and by some displacements of landform features after faults movements. These parallel lineaments or faults are oblique to the fold axis with an angle equal to $\left(50^{\circ}\right)$ and they bound the outcrop of Bekhme Formation. The location of the Bekhme Fn. is not in the middle part of the anticline and this may be controlled by the displacements of these two faults. It is also noticed that the interpretations of satellite imagery reveal that the extension of the listric fault trace was bounded by these two parallel faults.

\section{ENHANCEMENT OF SATELLITE IMAGERY}

An efficient scheme for digital classification method was executed and implemented by using (Integrated Soft-ware of Multispectral Image Classification ISMIC1.0). This program depends on the spectral analysis and used to recognize the classes by relative spectral differences (Al-Shumam, 2001). The applied satellite image which was taken from Google earth program (Ignosat 2002) (Fig.3), contains true colors and can be divided into three bands (Red, Green and Blue). These three bands were merged to produce false color composite by (ISMIC1.0) and creating an unsupervised classification (K- mean classification) for Shaikhan Anticline. Interpretation of the program product simplified the identification of the longitudinal fault trace (i.e. the listric fault).

\section{SHAIKHAN ANTICLINE AND THE LISTRIC FAULT}

Field data collection for analyzing this fold was taken from a traverse that crossed the anticline along the road joining Ain Sifni - Atrosh towns (Fig. 2). 


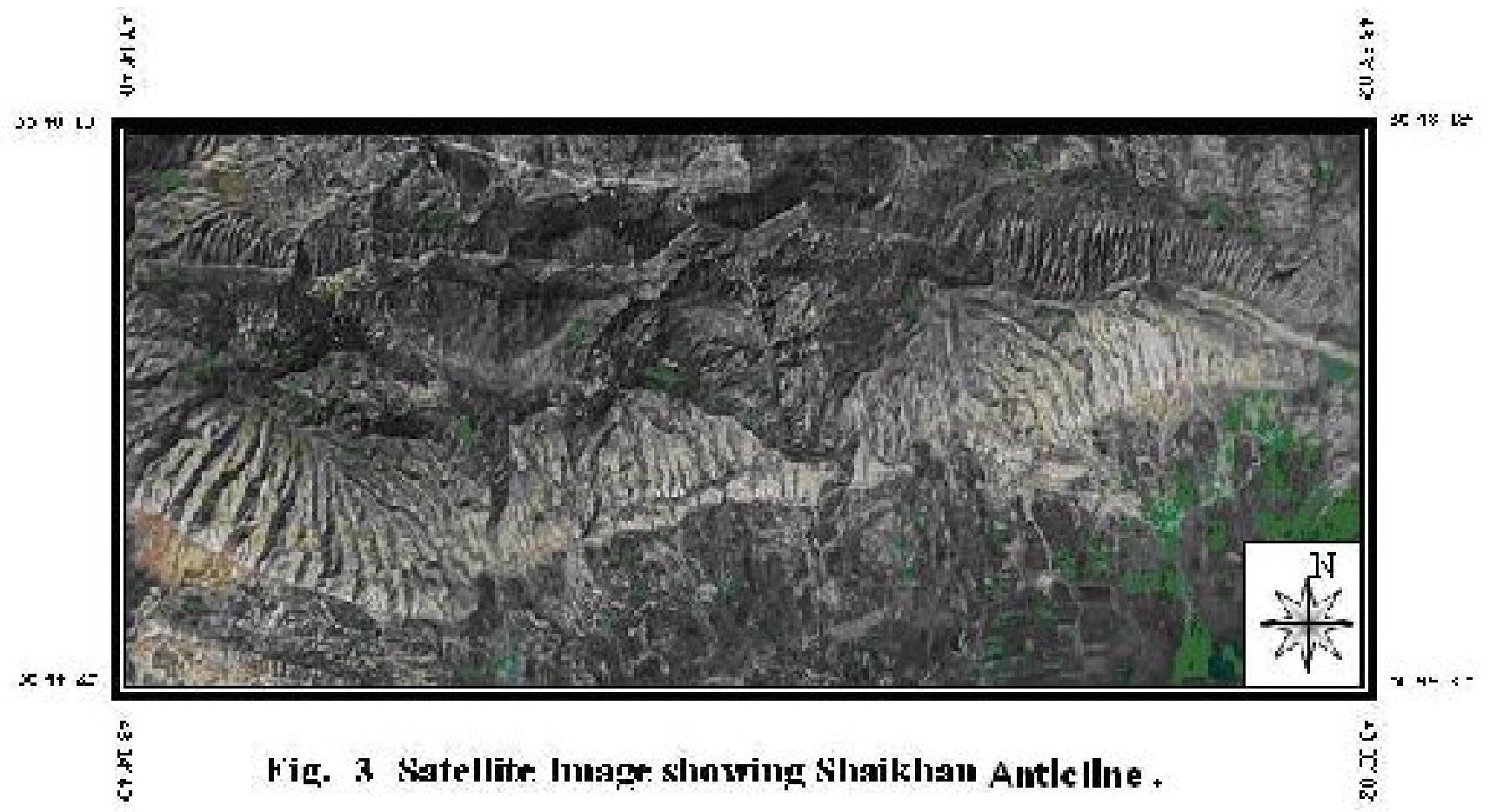

The geometric analysis of this fold revealed the following properties. It is an asymmetrical anticline with gentle southwestern limb (the average dip is $20{ }^{\circ}$ ) and steep northeast limb (the average dip is $400^{\circ}$ ). Therefore, the anticline is verging towards the northeast, in this traverse. Moreover the anticline is plunging $\left(5^{\circ}\right)$ towards WNW and the attitude of fold axis is $275 / 5$ (dip direction/dip amount). So the anticline is, precisely, trending west northwest - east southeast. The fold is considered as an open one because its interlimb angle is equal $1200^{\circ}$, and its axial plane attitude is $276 / 96$ (strike direction/dip amount) (Fig. 4).

Ramsay and Huber (1987) suggested that the competent beds (like the Pila Spi Fn.) can be bended by parallel type of folding because it maintained their bed thicknesses during folding. Whereas, the incompetent beds (like the Gercus and Kolosh Fn.) follows the folding of class 1C or class 3 styles of Ramsay (1967). Fourier analysis revealed that this fold has a Sinusoidal-Parabolic shape, indicating middle age of the folding growth with respect to the ages of the Foreland Folds of Iraq (Al-Azzawi, 2003).

Numan and Al-Azzawi (1993) suggested that vergence of most of the Foreland Folds were controlled by listric faults. These faults made the anticlines verged towards the north or northeast and south or southwest according to which type of fault the fold was subjected. The following items are a brief description of the listric faults history according to the description of Numan (1997) in the plate tectonic scenario of Iraq. Firstly: these listric faults were formed as normal type to accommodate the extension of the Arabian Plate at the Triassic period. Secondly: the formation of the suspended basins as a result of the normal displacement of these faults. Thirdly: the movement inversion of these faults from normal to reverse due to the tectonic inversion from extension to compression at the Cretaceous Period. Fourth: the 


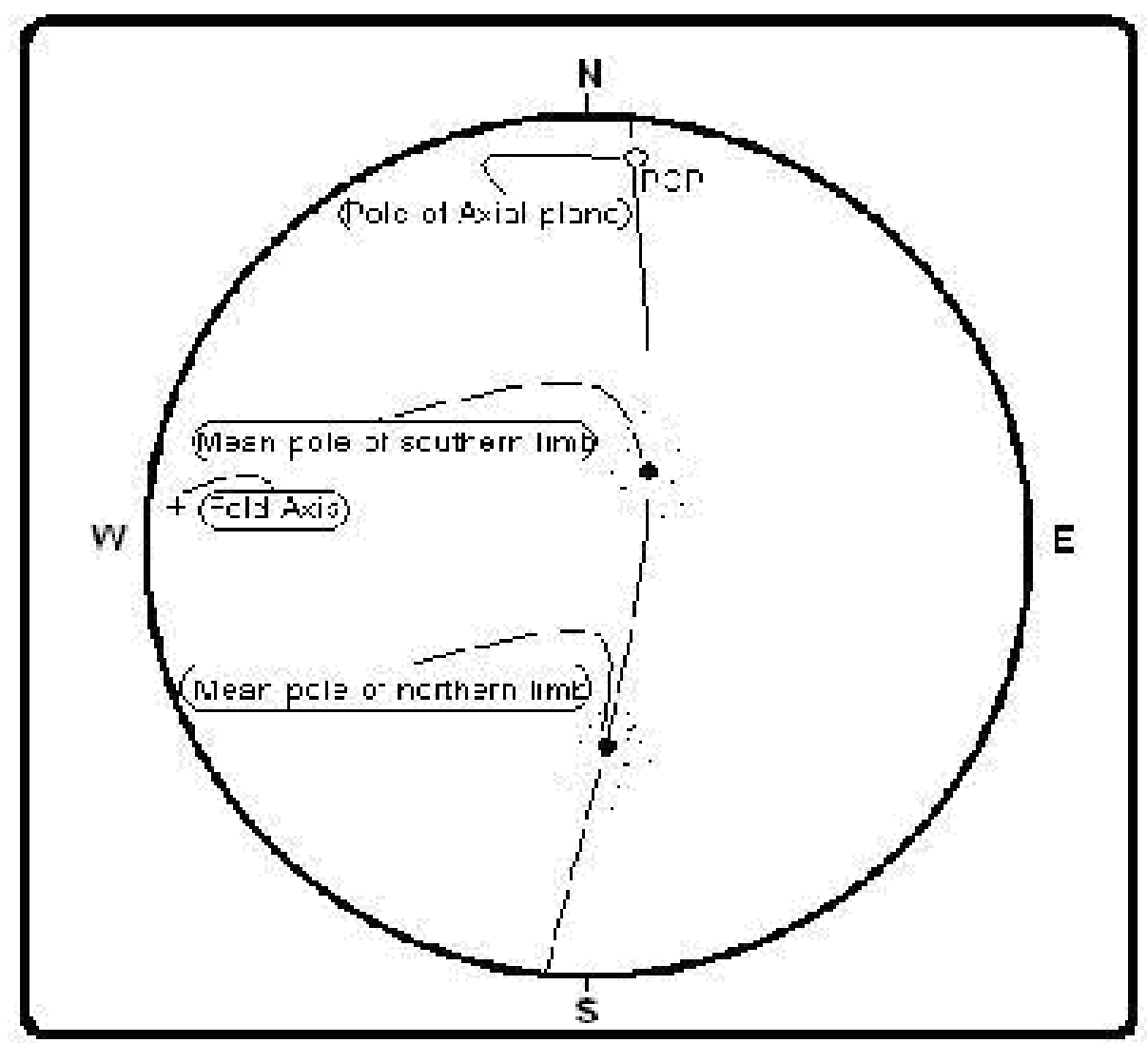

Fig. 4 Pi-Diagram of Shaikhan Anticline.

rejuvenations of the reverse movements on these faults due to the collision of Arabian and Iranian / Turkish plates during the Eocene period. Sommaruga (1997) and Al-Azzawi (2003) classified these fold related faults into two genetic types. Firstly:

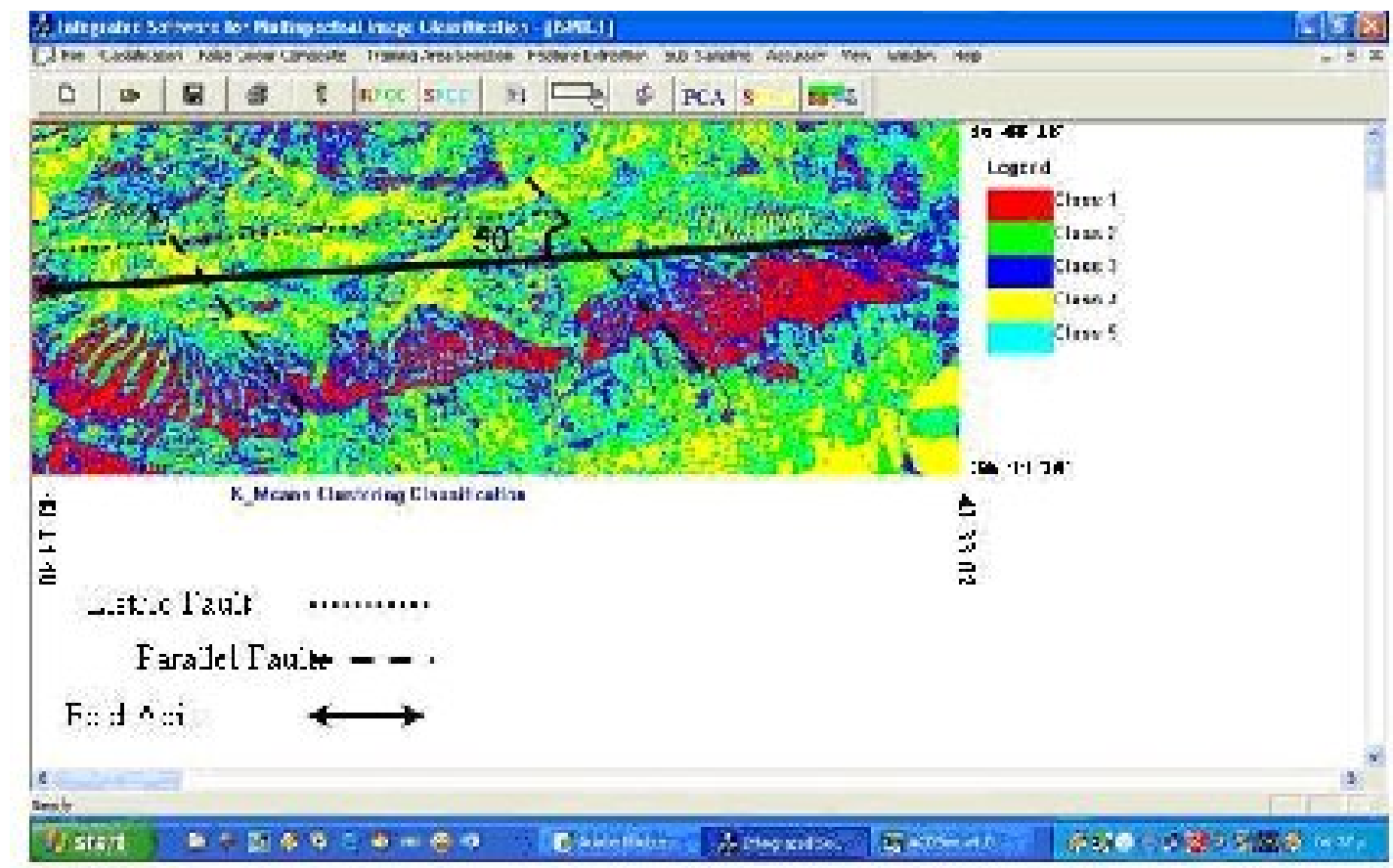

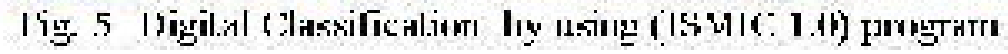


Foreland listric faults which are synthetic and were influenced folds and made them verge toward the south or southwest. Secondly: antithetic Suture or Hinterland listric faults which are made folds verging toward north or northeast. Some of these listric faults cut through the sedimentary cover and are exposed at the surface, whereas others are blind. Al-Azzawi (2003) was previously considered Shaikhan Anticline as asymmetrical and north-verging anticline with blind suture listric fault.

In the present study, the trace of the listric fault can not be detected during the general geological surveying of Shaikhan Anticline while the interpretation of the aerial photographs revealed the trace of this fault but not in certain manner (Fig. 2). Enhancement and interpretation of the satellite imagery by false color composite manifested this trace clearly (Fig. 5). This trace was extended in the satellite image in an area of about (14) km length. Then a detailed field work survey was carried out on the area adopted by satellite imagery. During the course of detailed survey a normal fault was detected and its location and extent coincides with the lineament of the satellite imagery. This normal fault cuts through the limestone beds of the Pila Spi Fn. at the northeastern limb but it appears to have a small displacement.

\section{THE FOLD/FAULT AGE RELATIONSHIP}

Because (Numan and Al-Azzawi, 2002) proposed the paroxysmal folding of the Foreland Folds at Pliocene period, the age of fault reactivation movement leads to decide the fold/fault relationship. So what is the origin of the fault movement? Is it of post-folding, syn-folding or pre-folding origin? To determine the origin of this movement, a procedure proposed by the authors was used for this purpose. It uses thickness variations of rock units at the opposite limbs of this anticline (Fig. 6). Therefore, if there are differences in the formation thicknesses, then the fault had a pre-folding movement. But if these thicknesses are not changed then the fault has a post-folding or synfolding movement. Therefore, the two possibilities can be discussed:

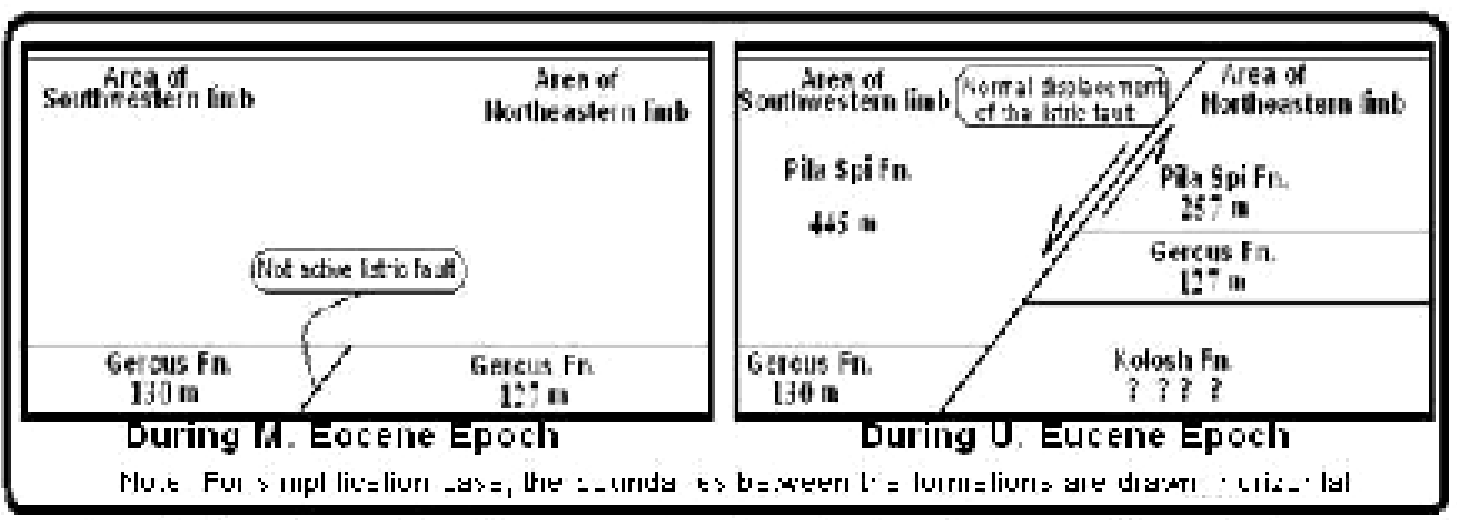

Fig. 6 A schematic diagram for the basin of deposition during M. and U. Eocene Epoch. 
1- During fold formation of an asymmetrical folded surface, the primary compressive stress will be analyzed into two secondary stresses. One of these stresses is a tension type acting on the gentle limb of an anticline and may forming a normal fault, whereas a compressive stress plays on the steeper limb and produces reverse or thrust faults (Al-Azzawi and Al-Dulaymi, 2002).Van der Pluijm and Marshak (1997) also suggested that reverse faults could form at the steeper limb during fold formation. This fold called a fault-inception fold. The above two references emphasized that a reverse fault can be developed at the steeper limb of an anticline due to folding. Hence the fault that disturbed the steeper limb of Shaikhan Anticline is of normal type; therefore its movement is not a syn-folding origin. It is also not post-folding type because the fault displacement influenced the thicknesses of Pila Spi Formation but not the Gercus Formation. Nevertheless the tectonic force is still acting on the Foreland Fold Belt and the folding operation is still growing up (Hardenberg, 2003; Al-Azzawi, 2003).

2- Another possibility is that the fault movement is of pre-folding or syndepositional origin like the origin of listric fault. The procedure used for checking this possibility is depends on the formation thickness change. For this purpose, true thicknesses of the Pila Spi and Gercus formations in both northeastern and southwestern limbs were measured in the field (Table 1).

\begin{tabular}{|c|c|c|c|}
\hline Fn. & Age & NE limb & SW limb \\
\hline Pila Spi & M. - U. Eocene & $257 \mathrm{~m}$ & $445 \mathrm{~m}$ \\
\hline Gercus & M. Eocene & $127 \mathrm{~m}$ & $130 \mathrm{~m}$ \\
\hline
\end{tabular}

Table (1) True thicknesses of Pila Spi and Gercus formations.

True thickness of the Pila Spi Fn. was calculated by multiplying the outcrop width by the sine of dip angle of the formation beddings, whereas multiplication of the horizontal distance by the tangent of the shooting angle was used for determining the thickness of the Gercus Formation. Where the horizontal distance is the line length between location of the theodolite shooting and the outcrop of this formation, and the shooting angle is the angular difference between the upper and lower points of the Gercus Fn. measured by the theodolite. This method was used because the Gercus Fn. outcrops appeared as cliffs in the studied area. Table (1) shows that the thickness values of the Gercus Fn. in the northeast and southwest limbs were mostly equal. This indicates that the paleogeography of the Gercus Basin was rather flat. While the thickness values of the Pila Spi Fn. show very large difference between the two limbs. It means that the Pila Spi Basin at the area of the southwestern limb was highly subsided relative to the uplifted area of the northeastern limb (Fig.6). In the field, the fault plane manifested dipping southwesterly. Consequently, this is an indication of normal displacement which is an evidence of the suture listric fault. This conclusion and Figure (6) may reveal that the normal displacement of this fault took place at the Upper Eocene period. 


\section{DISCUSSION}

The previous studies proposed that there is a blind listric fault that influenced the northeastwards vergence of this anticline. The present study detected a longitudinal fault that extends about (14) $\mathrm{km}$ along the northeastern limb of this anticline. The occurrence of this fault was sustained by a detailed field surveying. The origin of the fault movement, whether it is pre-folding, syn-folding or post-folding, was also discussed. It was found that it is of Pre-folding origin and compatible with the origin of the listric faults.

Numan (1997) and Al-Azzawi (2003) suggested that the listric faults were formed when Arabian Plate had been splited from the Iranian and Turkish plates and the extension phase was dominant, inversion in the type of movement from normal to reverse when the extension phase inverted to compression at the Upper Cretacous and rejuvenated by reverse movement at the Middle Eocene Epoch. These listric faults are two types. The foreland listric faults are verging towards the Foreland (southwestwards). While the suture listric faults are verging towards the suture of the orogeny. These two types were reactivated as reverse faults at the Middle Eocene Epoch.

In the present work, it was found that some of the suture listric faults might be reactivated as normal faults (i.e. the present studied anticline and Sinjar Anticline); comparing with the previously known reverse movement of the foreland listric faults. It is also emphasize that this suture listric fault was inactive till the Middle Eocene Epoch and began its reactivation at the Upper Eocene period by a normal sense of displacement. It means that the fault was rejuvenated simultaneously with the beginning of the fold formation when the Arabian Plate was collided with the Iranian and Turkish plates. It was also noticed that the displacement of this fault was continued during the fold formation and dieing out with the fold growth or might be changing its movement from normal to reverse in the final stage. This is evident by the small displacement at the top of limestone beds of the Pila Spi Fn.

Finally, it is not reliable to simply consider this fault as pre-folding or syn-folding origin only. This is because the listric faults were formed from the Triassic period (pre-folding) and rejuvenated at the Cretaceous and the Upper Eocene period (syn-folding).

\section{CONCLUSIONS}

Geomorphologic and structural investigations of Shaikhan Anticline revealed the following conclusions:

1- The location of the Bekhme Fn. is not in the middle part of the anticline, and this was controlled by two parallel faults which are oblique to the fold axis.

2- There is a longitudinal fault existing $14 \mathrm{Km}$ along the northeastern limb of Shaikhan Anticline. This fault was detected by the aerial photography, the satellite imagery and the field observations. 
3- There is no evidence for any displacement of this fault during the deposition of the Gercus Fn. (M. Eocene).

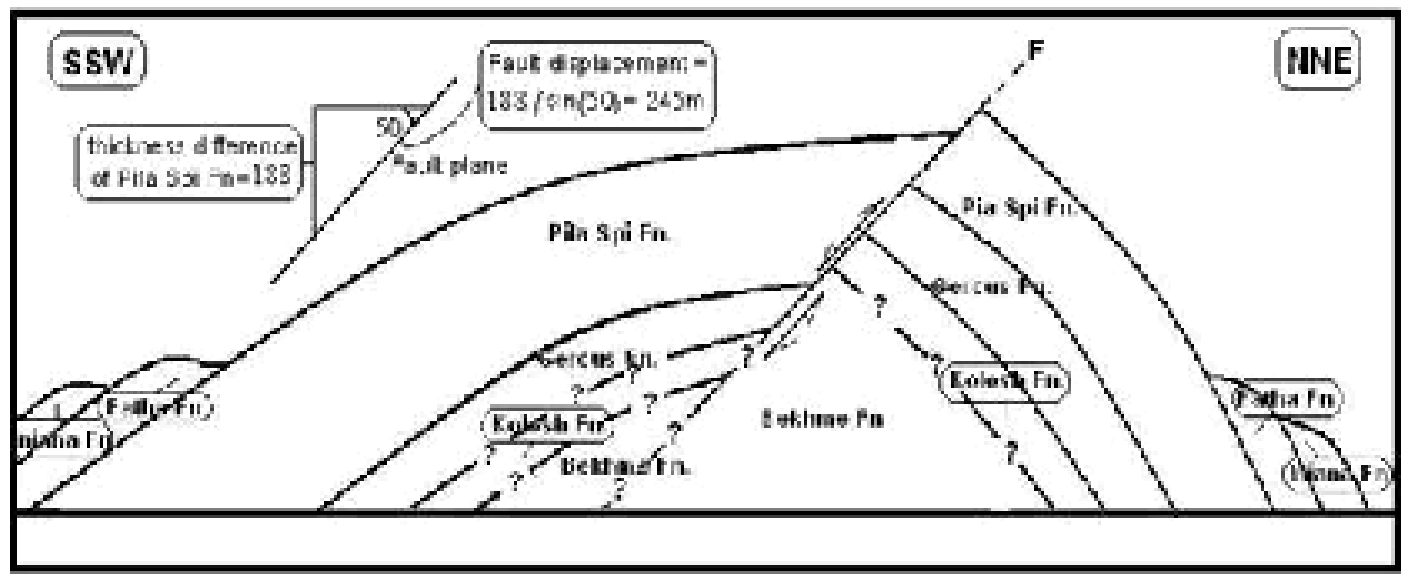

Fig. 7 A schematic cross-section of Shaikhan Anticline with the associated listric fault.

4- An evidence of a normal displacement (relatively subsidence of the southwestern limb) existed during the deposition of the Pila Spi Fn. This indicates that a normal displacement was taking place during the Upper Eocene Epoch.

5- The net slip of the Upper Eocene normal displacement of the listric fault was calculated and it is about $245 \mathrm{~m}$, whereas the vertical displacement is equal to the thickness difference between the northeastern and southwestern limbs $(188 \mathrm{~m})$. The net slip displacement $(245 \mathrm{~m})$ was found by [188/ $\sin (50)]$, where the angle $50^{\circ}$ is the dip angle of the fault plane which was measured directly in the field (Fig. 7).

6- Finally, it could be concluded that the fault which was identified using aerial photographs and satellite imagery and that cuts through the beddings of the Pila Spi Fn., is of listric type that previously believed to be a blind fault. This listric fault has the properties of suture type and it was reactivated by normal displacement during the Upper Eocene Epoch. This fault might be inversed its sense of movement through post- Upper Eocene. This is proving the small displacement appeared on the sedimentary cover.

\section{REFERENCES}

Ahmad, M. A.,1980. Geology of Shaikhan Area, Unpublished M. Sc Thesis, College of Science, University of Mosul.

Al-Azzawi, N. K. B., 2003. The Structural Development of Fold Shape in the Foreland Belt of Iraq and Its Tectonic Implications, Unpublished $\mathrm{Ph} . \mathrm{D}$ Thesis, College of Science, University of Mosul. 
Al-Azzawi, N. K. B., and Al-Dulaymi, M. M. 2002. Geometry and Origin of Joints of Bahshiqa Area, Iraqi Jour. of Earth Science, Special Issue, VOL.2, No. 2, p 110-124.

Al-Shumam, T. A. 2001. An Integrated Software for Remotely Sensed Data Classification, M.Sc. Thesis, College of Science, University of Mosul.

Hardenberg, M. F., 2003. Tectonic and Sedimentation of Early Continental Collision in Eastern Mediterranean (northeast Syria), Unpublished Ph.D Thesis, University of Edinburdg.

Marouf, N. Z., 1999. Dynamic Evolution of Sedimentary Basins in Northern Iraq and Hydrocarbon Formation, Migration and Entrapment, Unpublished Ph.D thesis, University of Baghdad, Iraq.

Numan, N. M. S., and Al-Azzawi, N. K. B., 1993. Structural and Geotectonic Interpretation of Vergence Directions of the Anticlines in the Foreland Folds of Iraq, Abhath Al-Yarmouk (pure science and engineering), Yarmok University, Jordan, Vol. 2, No. 2, pp57-73.

Numan, N. M. S., 1997. A plate tectonic scenario for the Phanerozoic succession in Iraq, Geol. Soc. Iraq. Jour., 30, 2.

Numan, N. M. S., and Al-Azzawi, N. K. B., 2002. Progressive Versus Paroxysmal Alpine Folding in Sinjar Anticline Northern Iraq, Iraqi jour. of Earth Science, Vol. 2, No. 2, pp59-69

Ramsay, J. G., 1967. Folding and Fracturing of Rocks, McGraw Hill, New York, 568p.

Sommaruga, A.,1997. Geology of Central Jura and the Molasse Basin: New insights into an Evaporate-Based Foreland Fold and Thrust Belt, Mem. Soc. Neuchatel. Nat., XII, 1-176.

Van Bellen, R. C., Dunnington, H. V., Wetzel, R. and Morton, D. M., 1959, Lexique Stratigraphique International, National de la recherché scientifique, 13, quai, Anatole-France, Paris- VII, 333p.

Van der Pluijm, B. A., and Marshak, S., 1997. Earth Structure: An Introduction to Structural Geology and Tectonics, WCB/McGraw-Hill, USA, 495P. 